\title{
Upaya Marketing Public Relations dalam Revitalisasi Program Ria Jenaka Di TVRI untuk Menarik Penonton Milenial
}

\author{
Alan Somantri, Diah Ayu Candraningrum \\ alansumnatri7@gmail.com,diahc@fikom.untar.ac.id \\ Fakultas Ilmu Komunikasi, Universitas Tarumanagara
}

\begin{abstract}
The research was conducted to examine the Marketing Public Relations system carried out by TVRI in revitalizing its program, the Ria Jenaka program. This system was used as one of TVRI's efforts to attract television audiences, especially the humorous Ria program. This research was conducted with a qualitative method by explaining the findings of the Ria Jenaka program which turned out to be less attractive to television viewers based on the television audience survey results released by television program survey institutions. The author uses the method of collecting data from the results of interviews, observations, and documenting data. The author hopes that the results of the research using Public Relations Marketing can provide input to the Ria Jenaka program in order to attract TVRI audiences who are lost and make the TVRI program, especially the Ria Jenaka program, acceptable to the audience.
\end{abstract}

Keywords: Marketing, Revitalization Strategy, Millennial

\begin{abstract}
Abstrak
Penelitian dilakukan untuk mengetahui sistem Marketing Public Relations yang dilakukan oleh TVRI dalam merevitalisasi program Ria Jenaka. Cara ini dipakai sebagai salah satu upaya TVRI untuk menarik penonton televisi khususnya program Ria jenaka. Penelitian ini dilakukan dengan metode kualitatif dengan menjelaskan hasil temuan pada program Ria Jenaka yang ternyata kurang diminati oleh pemirsa televisi berdasarkan hasil survei penonton televisi yang dikeluarkan oleh lembaga survei program televisi. Penulis mengunakan metode pengumpulan data dari hasil wawancara, observasi, dan mendokumentasikan data. Penulis mengharapkan hasil dari penelitian mengunakan Marketing Public Relations ini dapat memberikan masukan pada program Ria Jenaka agar dapat menarik kembali penonton TVRI yang hilang dan menjadikan program TVRI khususnya program Ria Jenaka dapat diterima oleh penonton.
\end{abstract}

Kata Kunci: Strategi Marketing, Revitalisasi, Milenial

\section{Pendahuluan}

Berdasarkan hasil survey beberapa tahun lalu, televisi masih menjadi salah satu media utama penyampaian informasi bagi masyarakat. dari data tersebut menunjukkan bahwa penonton televisi masih di urutan pertama, urutan kedua media luar ruang, internet, dan di posisi akhir radio. Ada hal yang menarik dari data yang dihasilkan, diketahui bahwa penggunaan internet cukup tinggi, hal ini dapat diartikan bahwa masyarakat Indonesia semakin banyak menggunakan internet sebagai alternatif lain untuk berkomunikasi, mencari serta mendapatkan berbagai informasi. Padahal beberapa tahun yang lalu, tingkat penggunaan internet belum tinggi. Hal ini 
tidak lepas dari kemajuan teknologi yang sangat cepat. Sekarang ini, masyarakat dengan mudah mengakses internet hanya dari alat komunikasi seperti telepon genggam, sehingga informasi dapat didapat dengan cepat dan dari berbagai tempat, baik di kendaraan umum, kafe, tempat konser, rumah, maupun di tempat kerja. Hasil ini didapatkan berdasarkan survei dengan melibatkan lebih dari 17 ribu responden dengan usia di atas 10 tahun dan dilakukan di beberapa kota besar di Indonesia, yaitu Jakarta, Bandung, Yogjakarta, Semarang, Surakarta, Surabaya, Denpasar, Medan, Palembang, Makassar, dan Banjarmasin.

Televisi adalah media elektronik audio visual yang efektif memberikan informasi kepada masyarakat, melalui tayangan yang seolah-olah memindahkan realitas sebenarnya atas suatu kejadian kedalam layar. Keberadaan televisi yang diciptakan sebagai media komunikasi massa sudah melekat dalam kehidupan masyarakat modern dan dianggap dapat dijadikan sebagai sumber berita maupun hiburan yang dibutuhkan (Susanto, 2010)

Menurut Wardhani (2015), sebelum banyaknya stasiun televisi swasta, orang masih suka mendengarkan dan menonton program tayangan dari Televisi Republik Indonesia (TVRI). Kini lembaga penyiaran publik (LPP) tersebut sepertinya menjadi kelas satu di dunia penyiaran di Indonesia. TVRI telah menjadi Lembaga penyiaran publik (LPP). TVRI mempunyai kewajiban memberikan informasi-informasi yang beragam melalui program program acaranya. Informasi yang diberikan bersifat independen, aktual, dapat diterima oleh semua kalangan, tidak memihak baik kepada mayoritas maupun minoritas, informasi yang disajikan menenangkan masyarakat dan mendidik masyarakat, serta menjangkau seluruh Indonesia.

Ria Jenaka merupakan program acara televisi yang disiarkan oleh TVRI yang menghadirkan tokoh-tokoh punakawan. Dengan durasi tayang 15 menit per episode Ria Jenaka tampil setiap sabtu minggu pukul 08.15 WIB. Program ini mulai ditayangkan pada saat Drs. H. Subrata menjabat direktur utama TVRI, program ini dibuat sebagai salah satu wadah penyampaian program-program pemerintah, agar dapat disosialisasikan dengan baik kepada masyarakat melalui televisi. Ria jenaka memakai unsur-unsur kebudayaan Jawa seperti alat musik dan tokoh-tokoh yang di perankannya.

Televisi juga termasuk sarana komunikasi, yang bersifat terbuka dan umum, artinya komunikasi massa itu ditunjukkan untuk semua orang, tidak ditunjukkan untuk sekelompok orang tertentu ,sehingga bersifat umum. Pesan komunikasi masa dapat berupa fakta, peristiwa, atau opini. Namun tidak semua fakta dan peristiwa yang terjadi dimuat di media massa, pesan komunikasi massa harus memenuhi kriteria aktual, informatif dan berguna untuk pemirsa televisi (Romli, 2016).

Program-program di televisi juga membawa unsur-unsur kebudayaan, budaya dapat menolong orang untuk saling mengenal di dunia ini. Meskipun lahir dengan anatomi dan fisiologis yang dibutuhkan untuk hidup di dunia ini, kebudayaan merupakan elemen subjektif dan objektif yang dibuat manusia pada masa lalu yang dapat diambil dan di pelajari dalam menonton televisi, dengan demikian mereka dapat berkomunikasi satu sama lainnya, karena mereka mempunyai kesamaan bahasa dan mereka hidup dalam waktu dan tempat yang sama (Larry 2010)

Yang telah kita ketahui, seni budaya perlu dilestarikan sehingga komunikasi antar budaya dalam masyarakat terus terjaga dan tersosialisasikan, menurut Dwi Suyanto seni budaya dapat membangun kepribadian bangsa yang ber-bhineka tunggal ika. Memperkuat kearifan lokal sebagai falsafah nilai dalam hidup berbangsa dan bernegara. Tak jarang setelah menonton pesan seni memberikan dampak positif 
Alan Somantri,Diah Ayu Candraningrum: Upaya Marketing Public Relations dalam Revitalisasi Program Ria Jenaka di TVRI untuk Menarik Penonton Milenial

bahkan ada yang hingga peduli pada pelestarian dan pengembangan potensi seni budaya.

\section{Metode Penelitian}

Dalam penelitian ini, penulis akan membahas tentang metodologi yang digunakan untuk melakukan penelitian ini. Penulis memutuskan untuk menggunakan pendekatan kualitatif, penelitian kualitatif merupakan prosedur penelitian yang menghasilkan data deskriptif berupa kata-kata tertulis atau lisan dari orang-orang dan perilaku yang dapat diamati. Pendekatan kualitatif diarahkan pada latar dan individu tersebut secara utuh (holistic) sehingga tidak boleh mengisolasikan individu atau organisasi ke dalam variable atau hipotesis, tetapi perlu memandangnya sebagai bagian dari suatu keutuhan. Penelitian kualitatif adalah tradisi tertentu dalam ilmu pengetahuan sosial yang secara fundamental bergantung dari pengamatan pada manusia baik dalam kawasannya maupun dalam peristilahannya.

Penerapan penelitian kualitatif dapat dipergunakan untuk melakukan penelitian yang memiliki hubungan dengan segala aspek dalam kehidupan masyarakat,antara lain sejarah, tingkah laku, fungsional operasional, dan hubungan-hubungan kekerabatan dalam kekeluargaan. Pendekatan kualitatif itu sendiri diharapkan mampu menghasilkan suatu uraian mendalam tentan ucapan, tulisan, dan tingkah laku yang dapat diamati dari suatu individu, kelompok, masyarakat, organisasi tertentu dalam suatu konteks setting tertentu yang dikaji dari sudut pandang yang untuh, komprehensif, dan holistik (Ruslan, 2012:15).

Teknik pengumpulan data dalam penelitian ini menggunakan wawancara, observasi, reduksi data, penyajian data penarikan kesimpulan, narasumber. Teknik ini digunakan untuk membantu penelitian ini mendapatkan data yang akurat.

\section{Hasil Temuan Dan Diskusi}

Saat ini TVRI selain mengudara dengan sistem analog juga telah mengudara dengan sistem siaran digital, dengan 4 kanal digitalnya yaitu: TVRI Nasional (juga dapat disaksikan melalui kanal digital), TVRI 2, 3 dan TVRI Sport HD. TVRI saat ini sedang menguji coba siaran secara digital secara bertahap di seluruh wilayah Indonesia. Saat ini TVRI mendapatkan hak siar laga pra musim International Champions Cup (ICC) sejak 2018 bersama iNews. Pada awal tahun 2019, TVRI mendapatkan hak siar 10 turnamen bulutangkis dari badan bulutangkis dunia hingga 2021.

Ria Jenaka adalah satu program acara televisi yang pernah disiarkan oleh TVRI, disiarkanI setiap hari Minggu pagi. Menghadirkan tokoh-tokoh punakawan Semar, Petruk, Gareng, dan Bagong yang diperankan antara lain oleh Ateng ( Bagong), Slamet Harto (sebagai Gareng ), Sampan Hismanto (sebagai Semar), dan Iskak (sebagai Petruk). Acara ini biasanya memiliki cerita yang singkat dan padat pesan sosial. Dalam beberapa episode-nya beberapa tokoh ditambahkan sebagai pelengkap yaitu Mono (diperankan oleh Teten Ahmad) dan Sup Yusup. 


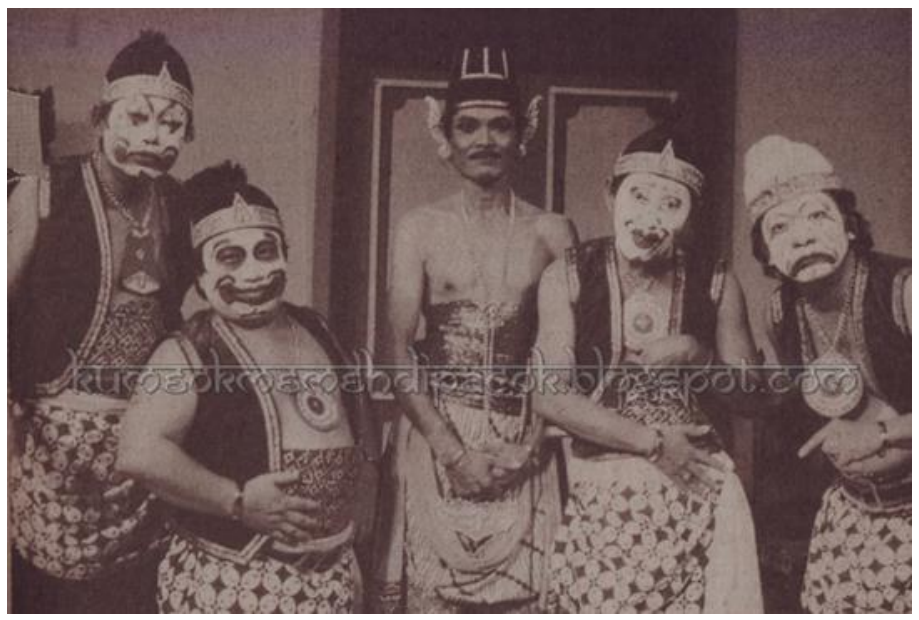

Gambar 1. Foto Ria Jenaka tahun 80 -an

Program ini mulai ditayangkan pada saat bapak Drs. H. Subrata menjabat direktur utama TVRI, program ini dibuat sebagai salah satu wadah penyampaian program-program pemerintah, agar dapat disosialisasikan dengan baik kepada masyarakat melalui televisi. Adapun pemilihan kostum performer punakawan karena dianggap dapat lebih dekat dengan masyarakat .

Dan sekarang Ria Jenaka telah kembali disiarkan oleh TVRI. Ria Jenaka dengan tambahan kata "Milenial". Paara pemerannya berasal dari komika komika yang telah dikenal saat ini. Mereka antara lain Gilang Baskhara (Petruk), Babe Cabita (Bagong), Mamat Papua (Gareng) dan Arief Didu (Romo alias Semar), yang ke semua pemain tersebut berasal dari berbagai daerah di Indonesia. yang diantaranya seperti Priya Prayogha Pratama alias Babe Cabita berasal dari Medan dan Muhammed Yusran Alkatiri alias Mamat Papua yang berasal dari daerah Timur Indonesia, Papua. Yang menyukai jenis acara pelawak tunggal atau stand up komedi mungkin sudah familiar sekali dengan nama-nama di atas. Karena di antara mereka adalah para komika alumni Stand Up Comedy Academy (SUCA) dan Stand up Comedy Indonesia (SUCI), yang saat ini dalam proses audisi musim ke 8-nya dan masih dengan saluran TV yang sama, KompasTV.

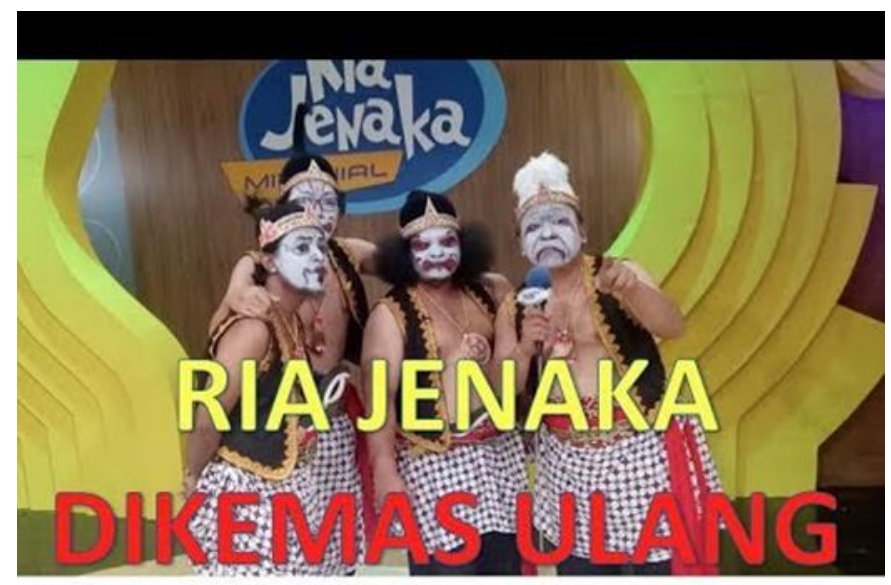

Gambar 2. Foto Ria Jenaka sekarang 
Dengan tayangan berdurasi 60 menit, Ria Jenaka milenial ini masih tetap menggunakan konsep pendahulunya, masih mencoba sedikit demi sedikit menyelipkan beberapa pesan lewat bahan lawakan yang berisikan ideologi pancasila, yang mengandung unsur persatuan dan keanekaragaman yang dibungkus rapi dengan sentuhan anak muda, dengan stand up comedy sebagai daya tariknya. Alhasil usaha sang raja kuis Helmi Yahya ini untuk membangkitkan kembali salah satu program acara legendaris era 80-an berhasil dengan polesan kekinian yang lebih segar, lebih menghibur dan masih tetap mampu mengkritisi permasalahan sosial dan hot issue yang muncul di tengah gempuran perkembangan dunia pertelevisian digital tanpa batas.

\section{Simpulan}

Ria Jenaka dalam menjalankan upaya revitalisasi program yang telah lama dan ingin muncul kembali dan ingin mengambil kembali penonton-penontonnya dari situ Ria Jenaka mengunakan Markerting Public Relations untuk melancarkan sebuah promosi program Ria Jenaka. Hal ini dapat dimaksudkan agar dalam mempromosikan program Ria Jenaka dapat dilaksanakan secara efektif dan efisien. Dalam melaksanakan strategi Markerting Public Relations, Ria Jenaka juga menggunakan bauran promosi yang meliputi promosi penjualan, pemasaran langsung, promosi iklan dan media sosial lainnya.

Kegiatan Marketing Public Relations itu memperkuat satu sama lain dalam mencapai kesuksesan Ria Jenaka. Ria Jenaka menggunakan Marketing Public Relations untuk mendukung kegiatan promosi yang lain seperti iklan-iklan di televisi, Intasgram, Twitter, Facebook, YouTube, dan media sosial lainnya. Marketing Public Relations bisa digunakan sebagai pembuka jalan bagi kegiatan promosi yang lain atau sebagi penguat setelah kegiatan promosi yang lain selesai di laksanakan. Mengingat karakteristik dari pasar yang dibidik oleh Ria Jenaka, hampir semua penonton yang pernah menonton atau mendengar program Ria Jenaka akan menceritakan kepada orang lain tentang program Ria Jenaka tersebut dan sebagian dari mereka akan melakukan posting di media sosial seperti Story di Instagram dan Snapchat. Hal ini memberikan efek yang luar biasa dalam melipatgandakan jumlah promosi di program Ria Jenaka.

\section{Ucapan Terima kasih}

Penulis mengucapkan terima kasih kepada seluruh narasumber, yaitu Bapak Yuniarto selaku Produser program ria jenaka, Ibu Hilda selaku Tim kreatif, Pak Budiman selaku petugas bidang penjualan dan pemasaran, Tamada selaku penonton televisi, dan Taufik selaku penonton TVRI. Yang telah berkerja sama dan memberikan waktu dalam proses pengumpulan data penelitian ini. Kemudian ucapan terima kasih juga diberikan kepada Dosen Fakultas Ilmu Komunikasi Universitas Tarumanagara yang telah memberikan bimbingan dan arahan atas terselesainya penelitian ini. 


\section{Daftar Pustaka}

Romli, Khomsahrial. 2016. Komunikasi Massa. Jakarta: kompas gramedia Ruslan, Rosady. 2012. Manajemen Public Relations \& Media Komunikasi: Konsepsi dan Aplikasi. Jakarta: Rajawali Press

Samovar, Larry A. 2010. Komunikasi Lintas Budaya. Jakarta: Salemba Humanika

Setiawan, Conny R. 2010. Metode Penelitian Kualitatif. Jakarta: Grasindo

Susanto, eko harry. 2010. Komunikasi Manusia: Esensi dan Aplikasi dalam dinamika sosial ekonomi politik, Jakarta: mitra wacana media 